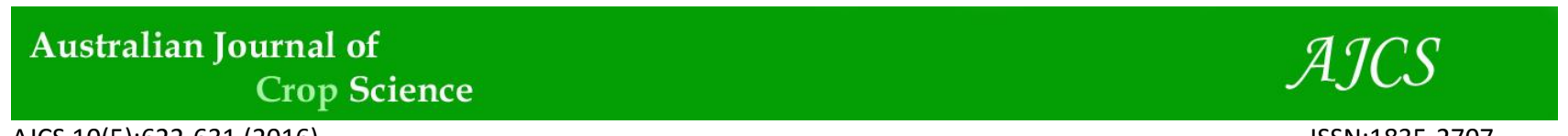

AJCS 10(5):622-631 (2016)

ISSN:1835-2707

DOI: 10.21475/ajcs.2016.10.05.p6853B

\title{
Nitrogen use of Panicum and Brachiaria cultivars vary with nitrogen supply: II Nitrogen use efficiency rankings and partition
}

\author{
Tiago Barreto Garcez, Francisco Antonio Monteiro* \\ Soil Science Department, ESALQ - University of São Paulo, Piracicaba, SP, Brazil \\ *Corresponding author: famontei@usp.br
}

\begin{abstract}
An improved $\mathrm{N}$ use in grasses is necessary to increase the nutrient use efficiency and the species persistence in the production systems. However, it is not known if the same grass cultivars should be used in high or low N situations to achieve high nitrogen use efficiency (NUE). This study aimed to analyze whether Brachiaria brizantha cv. Marandu, B. brizantha cv. Xaraés, B. brizantha cv. Piatã, $B$. decumbens cv. Basilisk, Panicum maximum cv. Mombaça, P. maximum cv. Tanzania, P. maximum cv. Aruana and $P$. maximum $x P$. infestum $\mathrm{cv}$. Massai grasses modify the $\mathrm{N}$ partition to an improved nutrient use efficiency when growing in an environment with low and high $\mathrm{N}$ availability. The experiment was carried out in a greenhouse with an Entisol collected in a degraded pasture area. The experiment was set up with 8 cultivars (four cultivars each of Brachiaria spp. and Panicum spp.) x $2 \mathrm{~N}$ rates in a complete randomized block design, with four replications. The studied grasses modified the $\mathrm{N}$ partition and the nitrate and ammonium concentrations in shoots and roots at high and low $\mathrm{N}$ supplied rates. These differences reflect the higher NUE by Mombaça and Tanzania compared with the other six cultivars.
\end{abstract}

Keywords: Ammonium; Concentration; Content; Nitrate; NUE. Abbreviations: N_Nitrogen, NUE_Nitrogen use efficiency

\section{Introduction}

Brazil has approximately 173 million hectares of pasture in its territory, and 102 million hectares of which are planted pastures. Planted pastures increased by $2.7 \%$ between 1996 and 2006 because of natural pastures replacement (IBGE, 2010). Most of the crops replacing natural pastures consist of grasses from the genera Brachiaria and Panicum, which are present in tropical and sub-tropical countries (Boddey et al., 2004; Vendramini et al., 2013). To elucidate the pasturebased animal production systems, studies have focused on grass species characteristics such as the yield, tolerance and persistence under conditions of stress, as well as forages nutritional value; the improvement of these characteristics requires the development and selection of cultivars better adapted to local environmental conditions (Humphreys et al., 2006; Yaseen and Malhi, 2009; Parsons et al., 2011; Rasmussen et al., 2012). Nitrogen is the most limiting nutrient for pasture production, and the increases in its availability in the soil results in higher yields and increased $\mathrm{N}$ concentrations and contents in forage plants (Lavres Junior et al., 2010; Silveira and Monteiro, 2010; Muir et al., 2013). Nitrate and ammonium are the major inorganic forms of $\mathrm{N}$ available to plants (Mahmood and Kaiser, 2003). When nitrate is absorbed, it can be reduced to ammonium and rapidly assimilated into organic compounds, or it can accumulate in vacuoles (Cárdenas-Navarro et al., 1999; Chen et al., 2004). Ammonium is rapidly converted to amino acids; however, ammonium can be highly toxic to plant cells when accumulated in excess (Marschner, 1995; Wang and Macko, 2011). Concentrations and contents of $\mathrm{N}$ in the plant shoots may be related to the proportion of structural and storage organs containing $\mathrm{N}$, which, in turn, modifies the production of plant dry matter (Greenwood et al., 1990; Primavesi et al., 2004; Corrêa et al., 2007; Yuan et al., 2007). Santos et al.

(2002) and Santos et al. (2012) observed that N taken up by the roots was the main source of $\mathrm{N}$ for new lateral tillers and leaves production of Panicum maximum cv. Tanzania and low $\mathrm{N}$ rates resulted in the mobilization of accumulated $\mathrm{N}$ from the shoots to the root system. Lemaire and Salette (1984) reported that cultivars with high dry matter production and $\mathrm{N}$ use efficiency (NUE) had low $\mathrm{N}$ concentrations in their plant tissues; the low $\mathrm{N}$ concentration in the tissues (and, therefore, the low crude protein) reduces plant nutritive value (Brégarda et al. 2000) and makes it difficult for ruminants to meet their nutritional requirements (Andrade et al., 2000; Vitor et al., 2009; Santos et al., 2010). According to Brégarda et al. (2000), biomass partitioning is the key to increase the NUE or N concentration in the tissues of plants. An understanding of how forage grasses use the absorbed $\mathrm{N}$ to improve the NUE and the persistence of this nutrient in the environment is required for the best utilization of grasses in the production system. This study aimed to examine whether the forage grasses Brachiaria brizantha cv. Marandu, $B$. brizantha cv. Xaraés, B. brizantha cv. Piatã, B. decumbens cv. Basilisk, Panicum maximum cv. Mombaça, P. maximum cv. Tanzania, $P$. maximum cv. Aruana and $P$. maximum $x P$. infestum cv. Massai grown in environments with low and high $\mathrm{N}$ availabilities alter their partitioning of absorbed $\mathrm{N}$ to improve this nutrient use efficiency.

\section{Results}

\section{Total N, nitrate and ammonium in the shoots}

The interaction $\mathrm{N}$ rates $\times$ cultivars was significant for the $\mathrm{N}$ concentrations and contents in grasses leaves and stems + 
Table 1. Nitrogen concentration and content in leaves and stems + sheaths at the first, second and third harvests of Brachiaria and Panicum cultivars grown at low and high nitrogen rates.

\begin{tabular}{|c|c|c|c|c|c|c|c|c|c|c|c|c|}
\hline \multirow[b]{3}{*}{ Cultivars } & \multicolumn{6}{|c|}{ Nitrogen concentration } & \multicolumn{6}{|c|}{ Nitrogen content } \\
\hline & \multicolumn{3}{|c|}{ Leaves } & \multicolumn{3}{|c|}{ Stems + sheaths } & \multicolumn{4}{|c|}{ Leaves } & \multicolumn{2}{|c|}{ Stems + sheaths } \\
\hline & Low $\mathrm{N}$ & High I & & $\overline{\text { Low I }}$ & & High N & Low N & & High N & & Low $\mathrm{N}$ & High N \\
\hline $1^{\text {st }}$ harvest & \multicolumn{6}{|c|}{$\mathrm{g} / \mathrm{kg}$} & \multicolumn{6}{|c|}{$\overline{\mathrm{mg}} / \mathrm{pot}$} \\
\hline Marandu & $17.5 \mathrm{ab}$ & 43.7 & a & 8.1 & $\mathrm{~b}$ & $23.9 \mathrm{ab}$ & 190.5 & $\mathrm{a}$ & 603.8 & $\mathrm{a}$ & $35.0 \mathrm{bc}$ & $120.4 \mathrm{~cd}$ \\
\hline Xaraés & $12.8 \mathrm{de}$ & 34.3 & $\mathrm{~b}$ & 7.0 & $\mathrm{bc}$ & $20.8 \mathrm{bc}$ & 179.0 & $a b$ & 650.3 & a & $42.4 \mathrm{bc}$ & $142.6 \mathrm{bc}$ \\
\hline Piatã & $20.1 \mathrm{a}$ & 43.7 & $\mathrm{a}$ & 10.8 & $\mathrm{a}$ & $26.2 \mathrm{a}$ & 197.8 & $\mathrm{a}$ & 332.8 & $\mathrm{~b}$ & $48.2 \mathrm{bc}$ & 70.8 \\
\hline Basilisk & $16.7 \mathrm{bc}$ & 33.3 & $\mathrm{~b}$ & 7.5 & $\mathrm{~b}$ & $16.2 \mathrm{de}$ & 157.5 & $\mathrm{bc}$ & 592.5 & $\mathrm{a}$ & 72.9 a & 281.9 a \\
\hline Mombaça & $9.7 \mathrm{f}$ & 22.3 & c & 4.9 & $\mathrm{~d}$ & $10.1 \mathrm{f}$ & 172.3 & $\mathrm{abc}$ & 715.3 & $\mathrm{a}$ & $37.9 \mathrm{bc}$ & $123.6 \mathrm{~cd}$ \\
\hline Tanzânia & $11.6 \mathrm{ef}$ & 24.4 & $\mathrm{c}$ & 5.9 & $\mathrm{~cd}$ & 12.2 ef & 167.8 & $\mathrm{abc}$ & 631.8 & $\mathrm{a}$ & $38.7 \mathrm{bc}$ & $130.4 \mathrm{bc}$ \\
\hline Aruana & $16.2 \mathrm{bc}$ & 36.4 & $\mathrm{~b}$ & 7.2 & $\mathrm{bc}$ & $18.1 \mathrm{~cd}$ & 142.8 & $\mathrm{c}$ & 593.5 & $\mathrm{a}$ & $39.6 \mathrm{bc}$ & $185.9 \mathrm{~b}$ \\
\hline Massai & $14.5 \mathrm{~cd}$ & 36.9 & $\mathrm{~b}$ & 7.1 & $\mathrm{bc}$ & $20.9 \mathrm{bc}$ & 173.3 & $\mathrm{abc}$ & 608.0 & $\mathrm{a}$ & $26.6 \mathrm{c}$ & $116.6 \mathrm{~cd}$ \\
\hline Mean & 14.9 & 34.4 & & 7.3 & & 18.5 & 172.6 & & 591.0 & & 42.7 & 146.5 \\
\hline \multicolumn{13}{|l|}{ F test } \\
\hline $\mathrm{N}$ & & $* *$ & & & & $* *$ & & & $* *$ & & & $* *$ \\
\hline Cultivar & & $* *$ & & & & $* *$ & & & $* *$ & & & $* *$ \\
\hline N x Cultivar & & $* *$ & & & & $* *$ & & & $* *$ & & & $* *$ \\
\hline $\mathrm{VC}(\%)$ & & 8.9 & & & & 10.1 & & & 11.1 & & & 14.0 \\
\hline
\end{tabular}

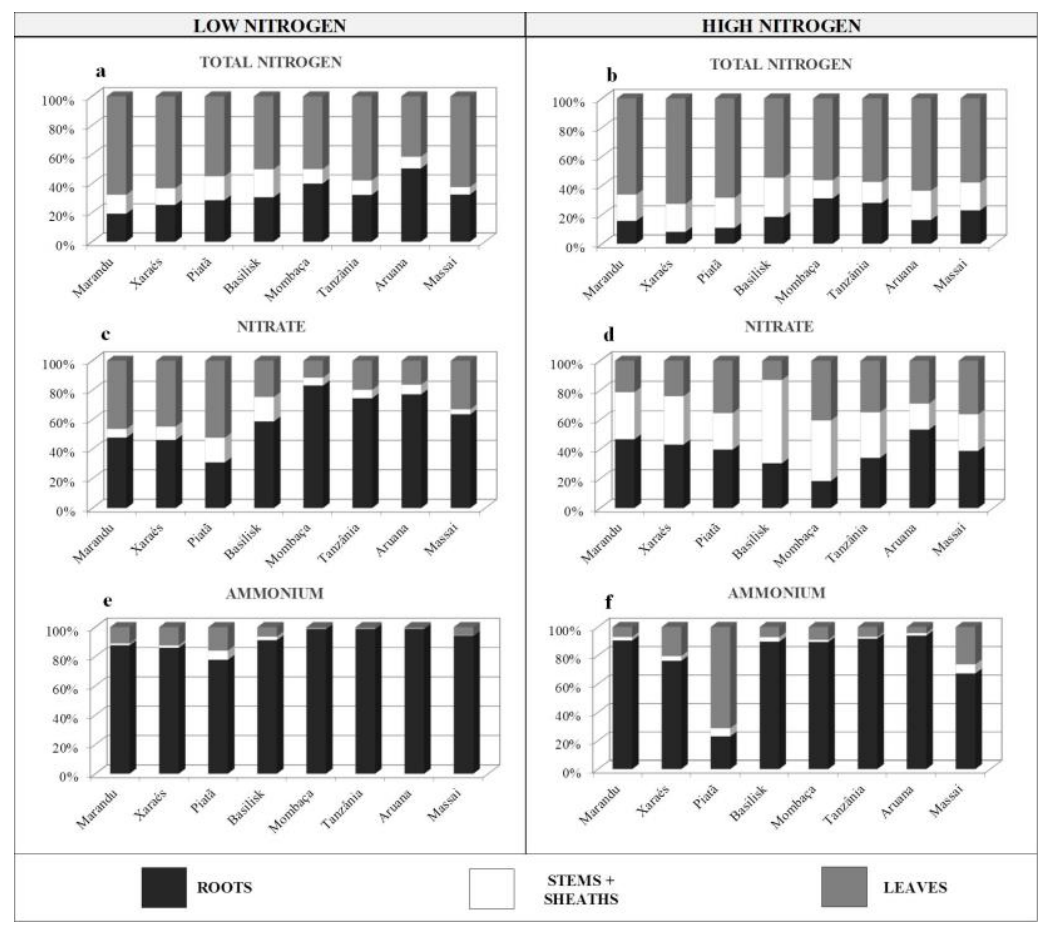

Fig 1. Proportion of the total nitrogen (a, b), nitrate (c, d) and ammonium (e, f) in the roots of Brachiaria and Panicum cultivars at the third harvest and under nitrogen rates.

sheaths collected in the three plant harvests (Table 1). Marandu and Piatã cultivars always had the highest leaf $\mathrm{N}$ concentrations when exposed to both $\mathrm{N}$ rates and Mombaça and Tanzania cultivars had the lowest leaf $\mathrm{N}$ concentrations for both $\mathrm{N}$ rates. The following total $\mathrm{N}$ concentrations were found in cultivars stems + sheaths exposed to low $\mathrm{N}$ rates: at the first harvest $\left(1^{\text {st }} \mathrm{H}\right)$, Piatã cultivar had the highest $\mathrm{N}$ concentration, while Mombaça and Tanzania cultivars had similarly low concentrations; at the second harvest $\left(2{ }^{\text {nd }} \mathrm{H}\right)$, Piatã cultivar had the highest $\mathrm{N}$ concentration, while the Mombaça cultivar had low $\mathrm{N}$ concentrations that were similar to the other Panicum cultivars; at the third harvest $\left(3^{\text {rd }} \mathrm{H}\right)$, Piatã cultivar had the highest N concentration, and Panicum and Xaraés cultivars had similarly low $\mathrm{N}$ concentrations in the stems + sheaths. At high $\mathrm{N}$ rate and for all three harvests (Table 1), Piatã and Marandu cultivars always had the highest $\mathrm{N}$ concentrations in stems + sheaths tissues, while Mombaça and Tanzania cultivars always had the lowest concentrations.

The $\mathrm{N}$ content in the leaves was lower in plants exposed to low $\mathrm{N}$ rate than at high $\mathrm{N}$ rate (Table 1). For all three plant harvests, the $\mathrm{N}$ contents in leaves of plants exposed to low $\mathrm{N}$ rate were similar among cultivars; cultivars with the lowest absolute values were Aruana at the first harvest, Mombaça and Basilisk at the second harvest and Piatã at the third harvest (although these concentrations were not significantly different from the concentrations in other cultivars). At high $\mathrm{N}$ rate, Piatã cultivar had the lowest foliar $\mathrm{N}$ content for all three harvests, whereas Xaraés, Aruana, Massai and Mombaça 
Table 2. Nitrate concentration and content in leaves and stems + sheaths at the first, second and third harvests of Brachiaria and Panicum cultivars grown at low and high nitrogen rates.

\begin{tabular}{|c|c|c|c|c|c|c|c|c|c|c|c|c|c|c|c|c|}
\hline \multirow{4}{*}{$\begin{array}{l}\text { Cultivars } \\
1^{s t} \text { harvest }\end{array}$} & \multicolumn{8}{|c|}{ Nitrate concentration } & \multicolumn{8}{|c|}{ Nitrate content } \\
\hline & \multicolumn{4}{|c|}{ Leaves } & \multicolumn{4}{|c|}{ Stems + sheaths } & \multicolumn{4}{|c|}{ Leaves } & \multicolumn{4}{|c|}{ Stems + sheaths } \\
\hline & \multirow{2}{*}{\multicolumn{2}{|c|}{$\begin{array}{l}\text { Low N } \\
\mathrm{g} / \mathrm{kg}\end{array}$}} & \multicolumn{2}{|c|}{ High N } & \multicolumn{2}{|c|}{ Low $\mathrm{N}$} & \multicolumn{2}{|c|}{ High N } & \multirow{2}{*}{\multicolumn{2}{|c|}{$\begin{array}{l}\text { Low N } \\
\mathrm{mg} / \text { pot }\end{array}$}} & \multicolumn{2}{|c|}{ High $\mathrm{N}$} & \multicolumn{2}{|c|}{$\bar{L}$} & \multicolumn{2}{|c|}{ High N } \\
\hline & & & & & & & & & & & & & & & & \\
\hline Marandu & 0.29 & a & 0.68 & $\mathrm{~b}$ & 0.31 & $\mathrm{a}$ & 2.88 & $\mathrm{c}$ & 3.19 & $a b$ & 9.33 & $\mathrm{ab}$ & 1.63 & $\mathrm{a}$ & 15.73 & $\mathrm{c}$ \\
\hline Xaraés & 0.19 & $\mathrm{~b}$ & 0.58 & $\mathrm{bc}$ & 0.15 & bcd & 2.58 & $\mathrm{~cd}$ & 2.63 & $\mathrm{bc}$ & 11.04 & $\mathrm{a}$ & 0.94 & $\mathrm{~cd}$ & 17.68 & $\mathrm{c}$ \\
\hline Piatã & 0.16 & $\mathrm{~b}$ & 1.47 & $\mathrm{a}$ & 0.17 & $\mathrm{bc}$ & 4.92 & $\mathrm{a}$ & 1.61 & de & 9.54 & $a b$ & 0.74 & $\mathrm{~d}$ & 15.61 & $\mathrm{c}$ \\
\hline Basilisk & 0.17 & $\mathrm{~b}$ & 0.41 & cde & 0.14 & $\mathrm{~cd}$ & 1.91 & $\mathrm{~d}$ & 1.58 & de & 7.24 & $\mathrm{bc}$ & 1.17 & $\mathrm{bc}$ & 30.93 & $\mathrm{a}$ \\
\hline Mombaça & 0.16 & $\mathrm{~b}$ & 0.28 & def & 0.05 & $\mathrm{e}$ & 0.38 & $\mathrm{e}$ & 3.36 & $\mathrm{a}$ & 8.76 & $a b$ & 0.37 & $\mathrm{e}$ & 4.84 & $\mathrm{~d}$ \\
\hline Tanzânia & 0.18 & $\mathrm{~b}$ & 0.21 & ef & 0.22 & $\mathrm{~b}$ & 2.25 & $\mathrm{~cd}$ & 2.57 & $\mathrm{c}$ & 5.64 & $\mathrm{c}$ & 1.35 & $\mathrm{ab}$ & 24.04 & $\mathrm{~b}$ \\
\hline Aruana & 0.15 & $\mathrm{~b}$ & 0.19 & $\mathrm{f}$ & 0.13 & $\mathrm{~cd}$ & 0.89 & $\mathrm{e}$ & 1.35 & $\mathrm{e}$ & 3.08 & $\mathrm{~d}$ & 0.97 & $\mathrm{~cd}$ & 8.04 & $\mathrm{~d}$ \\
\hline Massai & 0.16 & $\mathrm{~b}$ & 0.47 & bcd & 0.10 & de & 3.85 & $\mathrm{~b}$ & 1.96 & $\mathrm{~d}$ & 8.52 & $a b$ & 0.29 & $\mathrm{e}$ & 21.47 & bc \\
\hline Mean & 0.18 & & 0.54 & & 0.16 & & 2.46 & & 2.28 & & 7.90 & & 0.93 & & 17.29 & \\
\hline \multicolumn{17}{|l|}{ F test } \\
\hline $\mathrm{N}$ & & & $* *$ & & & & $* *$ & & & & $* *$ & & & & $* *$ & \\
\hline Cultivar & & & $* *$ & & & & $* *$ & & & & $* *$ & & & & $* *$ & \\
\hline $\mathrm{N} x$ Cultivar & & & $* *$ & & & & $* *$ & & & & $* *$ & & & & $* *$ & \\
\hline $\mathrm{VC}(\%)$ & & & 18.5 & & & & 18.9 & & & & 15.2 & & & & 19.9 & \\
\hline $2^{\text {nd }}$ harvest & \multicolumn{8}{|c|}{$\mathrm{g} / \mathrm{kg}$} & & & & & & & & \\
\hline Marandu & 0.10 & $\mathrm{a}$ & 0.35 & $\mathrm{~b}$ & 0.13 & $\mathrm{a}$ & 2.37 & $\mathrm{~b}$ & 0.85 & $\mathrm{a}$ & 6.29 & a & 0.75 & & 20.36 & $\mathrm{~b}$ \\
\hline Xaraés & 0.06 & bcd & 0.18 & $\mathrm{dc}$ & 0.10 & $a b$ & 1.72 & $\mathrm{c}$ & 0.58 & $\mathrm{bc}$ & 4.88 & $\mathrm{~b}$ & 0.47 & & 30.93 & $\mathrm{a}$ \\
\hline Piatã & 0.10 & $\mathrm{a}$ & 0.69 & $\mathrm{a}$ & 0.11 & $a b$ & 4.05 & $\mathrm{a}$ & 0.46 & $\mathrm{~cd}$ & 4.45 & $\mathrm{bc}$ & 0.46 & $\mathrm{~b}$ & 19.86 & bc \\
\hline Basilisk & 0.11 & $\mathrm{a}$ & 0.23 & $\mathrm{c}$ & 0.04 & $\mathrm{c}$ & 1.81 & $\mathrm{bc}$ & 0.55 & bcd & 3.92 & bcd & 0.23 & $\mathrm{c}$ & 31.13 & $\mathrm{a}$ \\
\hline Mombaça & 0.08 & $a b c$ & 0.14 & d & 0.05 & $\mathrm{c}$ & 0.24 & $\mathrm{e}$ & 0.85 & $\mathrm{a}$ & 5.00 & $a b$ & 0.22 & $\mathrm{c}$ & 3.40 & $\mathrm{e}$ \\
\hline Tanzânia & 0.04 & $\mathrm{~d}$ & 0.09 & d & 0.07 & $\mathrm{bc}$ & 0.91 & $\mathrm{~d}$ & 0.40 & $\mathrm{~d}$ & 3.07 & d & 0.21 & $\mathrm{c}$ & 12.45 & $\mathrm{~cd}$ \\
\hline Aruana & 0.09 & $a b$ & 0.11 & d & 0.05 & $\mathrm{c}$ & 0.26 & $\mathrm{e}$ & 0.68 & $\mathrm{~b}$ & 2.82 & d & 0.23 & $\mathrm{c}$ & 5.22 & $\mathrm{de}$ \\
\hline Massai & 0.05 & $\mathrm{~cd}$ & 0.11 & d & 0.05 & $\mathrm{c}$ & 0.39 & de & 0.51 & $\mathrm{~cd}$ & 3.16 & $\mathrm{~cd}$ & 0.08 & $\mathrm{~d}$ & 3.86 & $\mathrm{e}$ \\
\hline Mean & 0.08 & & 0.24 & & 0.08 & & 1.47 & & 0.61 & & 4.20 & & 0.33 & & 15.90 & \\
\hline F test & & & & & & & & & & & & & & & & \\
\hline $\mathrm{N}$ & & & $* *$ & & & & $* *$ & & & & $* *$ & & & & $* *$ & \\
\hline Cultivar & & & $* *$ & & & & $* *$ & & & & $* *$ & & & & $* *$ & \\
\hline $\mathrm{N} x$ Cultivar & & & $* *$ & & & & $* *$ & & & & $* *$ & & & & $* *$ & \\
\hline $\mathrm{VC}(\%)$ & & & 17.4 & & & & 22.1 & & & & 17.1 & & & & 27.4 & \\
\hline $3^{\text {rd }}$ harvest & & & & & & & & & & & & & & & & \\
\hline Marandu & 0.12 & $\mathrm{~b}$ & 0.48 & $\mathrm{~b}$ & 0.05 & $\mathrm{~b}$ & 1.67 & $a b$ & 0.65 & $\mathrm{a}$ & 6.53 & $\mathrm{a}$ & 0.10 & $\mathrm{bc}$ & 10.49 & $\mathrm{~b}$ \\
\hline Xaraés & 0.11 & $\mathrm{bc}$ & 0.34 & $\mathrm{c}$ & 0.04 & $\mathrm{~b}$ & 1.11 & $\mathrm{~b}$ & 0.50 & $\mathrm{~b}$ & 6.94 & $\mathrm{a}$ & 0.10 & $\mathrm{bc}$ & 10.55 & $\mathrm{~b}$ \\
\hline Piatã & 0.20 & $\mathrm{a}$ & 1.04 & $\mathrm{a}$ & 0.11 & $\mathrm{a}$ & 2.04 & $\mathrm{a}$ & 0.50 & $\mathrm{~b}$ & 2.85 & $\mathrm{~cd}$ & 0.17 & $\mathrm{ab}$ & 1.99 & $\mathrm{c}$ \\
\hline Basilisk & 0.06 & d & 0.28 & $\mathrm{c}$ & 0.07 & $a b$ & 1.74 & $a b$ & 0.23 & $\mathrm{c}$ & 4.54 & $\mathrm{~b}$ & 0.17 & $\mathrm{ab}$ & 23.03 & $\mathrm{a}$ \\
\hline Mombaça & 0.04 & d & 0.12 & d & 0.03 & $\mathrm{~b}$ & 0.30 & $\mathrm{c}$ & 0.44 & $\mathrm{~b}$ & 3.95 & $\mathrm{bc}$ & 0.11 & $a b c$ & 3.58 & $\mathrm{c}$ \\
\hline Tanzânia & 0.06 & $\mathrm{~cd}$ & 0.08 & d & 0.07 & $\mathrm{ab}$ & 0.15 & $\mathrm{c}$ & 0.49 & $\mathrm{~b}$ & 2.69 & $\mathrm{~cd}$ & 0.21 & $\mathrm{a}$ & 2.06 & $\mathrm{c}$ \\
\hline Aruana & 0.04 & $\mathrm{~d}$ & 0.08 & d & 0.06 & $\mathrm{~b}$ & 0.07 & $\mathrm{c}$ & 0.26 & $\mathrm{c}$ & 1.84 & $\mathrm{~d}$ & 0.12 & $a b c$ & 0.99 & $\mathrm{c}$ \\
\hline Massai & 0.06 & $\mathrm{~d}$ & 0.10 & d & 0.03 & $\mathrm{~b}$ & 0.12 & $\mathrm{c}$ & 0.45 & $\mathrm{~b}$ & 2.73 & $\mathrm{~cd}$ & 0.03 & $\mathrm{c}$ & 1.75 & $\mathrm{c}$ \\
\hline Mean & 0.09 & & 0.31 & & 0.06 & & 0.90 & & 0.44 & & 4.01 & & 0.13 & & 6.80 & \\
\hline F test & & & & & & & & & & & & & & & & \\
\hline $\mathrm{N}$ & & & $* *$ & & & & $* *$ & & & & $* *$ & & & & $* *$ & \\
\hline Cultivar & & & $* *$ & & & & $* *$ & & & & $* *$ & & & & $* *$ & \\
\hline $\mathrm{N} x$ Cultivar & & & $* *$ & & & & $* *$ & & & & $* *$ & & & & $* *$ & \\
\hline $\mathrm{VC}(\%)$ & & & 18.5 & & & & 26.0 & & & & 20.2 & & & & 27.0 & \\
\hline
\end{tabular}

Means followed by the same letter in each sub-column for each plant harvest are not significant at the $5 \%$ probability rate according to Tukey's test. **Significant at $1 \%$ probability.

grasses always had the highest values, even though other cultivars had statistically similar contents. At low $\mathrm{N}$ rate, Basilisk cultivar had the highest $\mathrm{N}$ content in stems + sheaths, whereas Massai cultivar had the lowest stems + sheaths $\mathrm{N}$ contents in all three harvests. At high $\mathrm{N}$ rate, for all three harvests, Basilisk cultivar had the highest $\mathrm{N}$ content in the stems + sheaths, while the Piatã cultivar had the lowest $\mathrm{N}$ content (Table 1). The interaction $\mathrm{N}$ rates $\times$ cultivars was significant for the nitrate concentrations and contents in leaves and stems + sheaths of grasses in all three harvests (Table 2). At low $\mathrm{N}$ rate, nitrate concentrations in leaves were ranked in the following order: $1^{\text {st }} \mathrm{H}$ : Piatã $>$ other seven grasses; $2{ }^{\text {nd }} \mathrm{H}$ : Marandu = Piatã = Basilisk = Mombaça $=$ Tanzania $=$ Aruana, Marandu $=$ Piatã $=$ Basilisk $>$ Xaraés $=$ Tanzania $=$ Massai and Aruana $=$ Mombaça $=$ Xaraés; $3{ }^{\text {rd }} \mathrm{H}$ : Piatã $>$ Marandu $=$ Xaraés, Xaraés $>$ Basilisk $=$ Mombaça $=$ Aruana $=$ Massai Xaraés $=$ Tanzania and Tanzania $=$ Basilisk $=$ Mombaça $=$ Aruana $=$ Massai. At high $\mathrm{N}$ rate, for all three harvests, the Piatã cultivar had higher leaf nitrate concentrations than other cultivars. At second harvest, Panicum and Xaraés cultivars had the lowest leaf nitrate concentrations. At third harvest, nitrate concentrations in 

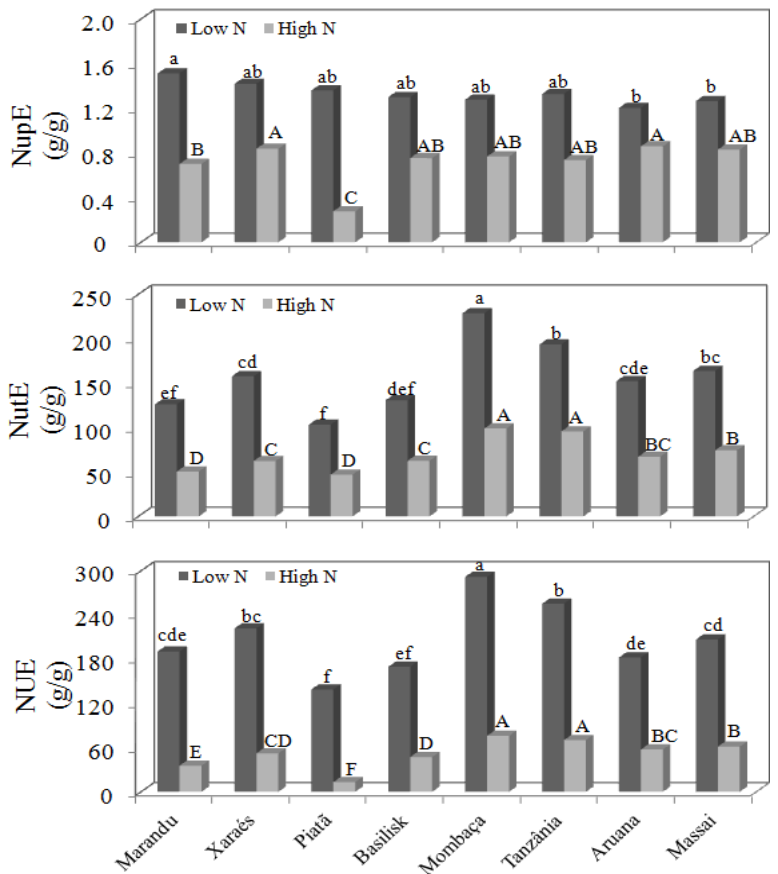

Fig 2. Nitrogen uptake efficiency - NupE (a), nitrogen utilization efficiency - NutE (b) and nitrogen use efficiency NUE (c) of Brachiaria and Panicum cultivars grown under low and high nitrogen rates (means followed by the same lowercase letter for the low nitrogen rates and uppercase letters for the high nitrogen rates were not significant at the $5 \%$ probability level).

leaves were ranked in the following order: Piatã > Marandu > Xaraés $=$ Basilisk $>$ Panicum spp. With low $\mathrm{N}$ rate, at first harvest, nitrate concentrations in the stems + sheaths were highest in Marandu cultivar; Mombaça cultivar had the lowest nitrate concentrations in the stems + sheaths but had statistically similar concentrations to Massai cultivar. At second harvest in low $\mathrm{N}$ rate, Marandu, Xaraés and Piatã cultivars had higher nitrate concentrations in the stems + sheaths than Basilisk, Mombaça, Aruana and Massai cultivars; Tanzania cultivar had similar nitrate concentrations to those of Xaraés and Piatã cultivars. At third harvest, with low $\mathrm{N}$ rate, Piatã cultivar had the highest nitrate concentrations in the stems + sheaths, followed by Basilisk and Tanzania (Table 2). At high $\mathrm{N}$ rate, Piatã cultivar had the highest nitrate concentration in the stems + sheaths for the first two harvests, while Mombaça and Aruana cultivars had the lowest nitrate concentrations. At third harvest, Brachiaria cultivars had higher nitrate concentrations in the stems + sheaths than Panicum cultivars (Table 2). Leaf nitrate contents of grasses supplied with low $\mathrm{N}$ rates were ranked in the following order: $1{ }^{\text {st }} \mathrm{H}$ : Mombaça $=$ Marandu, Mombaça > remaining cultivars, Aruana $=$ Piatã $=$ Basilisk and Aruana $<$ remaining cultivars; $2^{\text {nd }} \mathrm{H}$ : Marandu $=$ Mombaça $>$ remaining cultivars, with Tanzania having the lowest absolute value of nitrate content in the leaves but statistically similar values to Piatã, Basilisk and Massai cultivars; $3{ }^{\text {rd }} \mathrm{H}$ : Marandu > Xaraés $=$ Piatã $=$ Mombaça $=$ Tanzania $=$ Massai $>$ Basilisk $=$ Aruana. At high $\mathrm{N}$ rate, Marandu, Xaraés and Mombaça cultivars had the highest nitrate contents in their leaves for all three harvests, for the first and third harvests, and for the first and second harvests, respectively. At high $\mathrm{N}$ rate, Aruana cultivar had the lowest leaf nitrate content for all three harvests (Table 2). At low $\mathrm{N}$ rate, nitrate content in the stems + sheaths were ranked in the following order: $1{ }^{\mathrm{st}} \mathrm{H}$ : Marandu and Tanzania cultivars had the highest nitrate content, while Mombaça and Massai cultivars had the lowest nitrate contents; $2{ }^{\text {nd }} \mathrm{H}$ : Marandu and Massai cultivars had the highest and lowest nitrate content in the stems + sheaths, respectively; $3{ }^{\text {rd }} \mathrm{H}$ : Tanzania and Massai cultivars had the highest and lowest nitrate contents in the stems + sheaths, respectively. At high $\mathrm{N}$ rate, Basilisk cultivar had the highest nitrate content in the stems + sheaths for all three grass harvests (at the second harvest, only Xaraés cultivar had similar value to Basilisk). Panicum cultivars, especially Mombaça and Aruana, had the lowest nitrate contents in the stems + sheaths (Table 2).

The interaction $\mathrm{N}$ rates $\times$ cultivars for ammonium concentrations and contents in the leaves and stems + sheaths was significant in all three harvests; the only exception was ammonium concentration in the stems + sheaths of the first harvest (Table 3). Ammonium concentrations in leaves were similar among grasses, especially at high $\mathrm{N}$ rate. At low $\mathrm{N}$ rate, Piatã cultivar always had the highest ammonium concentration in the leaves, while Panicum spp., Tanzania (first harvest), Mombaça, Tanzania, Aruana and Massai (second harvest) and Mombaça and Aruana (third harvest) had the lowest foliar ammonium concentration. At high $\mathrm{N}$ rate, ammonium concentrations were different only in leaves collected at the second and third harvests. At the second harvest, ammonium concentrations were higher only in the leaves of Mombaça cultivar, while at third harvest, the ranking was: Piatã $>$ Xaraés > other studied cultivars. There was no clear pattern of response in the ammonium concentrations in the stems + sheaths of grasses. With low $\mathrm{N}$ rate, at the second harvest, ammonium concentrations in the stems + sheaths were highest in Marandu, Xaraés, Mombaça and Massai cultivars. However, at third harvest, Piatã cultivar was the only one that had higher ammonium concentrations than other cultivars. At high $\mathrm{N}$ rate, Marandu cultivar had the highest ammonium concentrations in the stems + sheaths. Conversely, Mombaça and Aruana cultivars always had the lowest ammonium concentrations in this part of the plant (Table 3).

Ammonium contents in shoots were higher at high $\mathrm{N}$ rate (Table 3). At low $\mathrm{N}$ rate, cultivars with highest leaf ammonium contents were as follows: Xaraés and Mombaça (first harvest); Xaraés, Piatã, Basilisk, Mombaça, Tanzania and Massai (second harvest); and Xaraés, Tanzania and Massai (third harvest). For the first and third harvests, Piatã cultivar had the lowest leaf ammonium contents. At high $\mathrm{N}$ rate, the highest ammonium contents were found in leaves of Mombaça, Tanzania and Massai (first harvest), Mombaça (second harvest) and Xaraés and Tanzania cultivars (third harvest); the lowest contents were found in Piatã (in the three harvests) and Basilisk cultivars (second and third harvests). At low $\mathrm{N}$ rate, grasses with highest ammonium contents in the stems + sheaths were Xaraés, Basilisk and Aruana (first harvest), Xaraés and Marandu cultivars (second harvest); for the third harvest, no differences were found among cultivars. At high $\mathrm{N}$ rate, differences in ammonium contents in the stems + sheaths among the grasses were evident, with Piatã cultivar having the lowest content for all three harvests and Basilisk cultivar having the highest values for the first harvest (Table 3).

\section{Total $N$, nitrate and ammonium in roots}

The interaction $\mathrm{N}$ rates $\times$ cultivars was significant for total $\mathrm{N}$, nitrate and ammonium concentrations and contents in roots (Table 4). At low $\mathrm{N}$ rate, Piatã and Xaraés had the highest absolute values of $\mathrm{N}$ concentrations in roots, while Tanzania 
Table 3. Ammonium concentration and content in leaves and stems + shelths at the first, second and third harvests of Brachiaria and Panicum cultivars grown at low and high nitrogen rates.

\begin{tabular}{|c|c|c|c|c|c|c|c|c|c|c|c|c|c|c|c|c|}
\hline \multirow{4}{*}{$\frac{\text { Cultivars }}{1^{\text {st }} \text { harvest }}$} & \multicolumn{8}{|c|}{ Ammonium concentration } & \multicolumn{8}{|c|}{ Ammonium content } \\
\hline & \multicolumn{4}{|c|}{ Leaves } & \multicolumn{4}{|c|}{ Stems + sheaths } & \multicolumn{4}{|c|}{ Leaves } & \multicolumn{4}{|c|}{ Stems + sheaths } \\
\hline & \multicolumn{2}{|c|}{ Low $\mathrm{N}$} & \multicolumn{2}{|c|}{$\overline{\text { High N }}$} & \multicolumn{2}{|c|}{ Low $\mathrm{N}$} & \multicolumn{2}{|c|}{ High N } & \multicolumn{2}{|c|}{ Low $\mathrm{N}$} & \multicolumn{2}{|c|}{ High N } & \multicolumn{2}{|c|}{ Low $\mathrm{N}$} & \multicolumn{2}{|c|}{ High N } \\
\hline & \multicolumn{8}{|c|}{$\overline{\mathrm{g}} / \mathrm{kg}$} & \multicolumn{8}{|c|}{$\overline{\mathrm{mg}} / \mathrm{pot}$} \\
\hline Marandu & 0.18 & $a b c$ & 0.23 & $\mathrm{a}$ & 0.15 & & 0.40 & & 2.00 & $\mathrm{~b}$ & 3.18 & $\mathrm{~cd}$ & 0.64 & $\mathrm{~b}$ & 2.00 & $\mathrm{~cd}$ \\
\hline Xaraés & 0.23 & $\mathrm{a}$ & 0.24 & $\mathrm{a}$ & 0.17 & & 0.35 & & 3.23 & $\mathrm{a}$ & 4.66 & $\mathrm{bc}$ & 1.02 & $a b$ & 2.37 & bcd \\
\hline Piatã & 0.20 & $\mathrm{ab}$ & 0.27 & $\mathrm{a}$ & 0.12 & & 0.32 & & 2.01 & $\mathrm{~b}$ & 2.03 & d & 0.53 & $\mathrm{~b}$ & 0.94 & $\mathrm{~d}$ \\
\hline Basilisk & 0.16 & $\mathrm{bc}$ & 0.26 & $\mathrm{a}$ & 0.13 & & 0.35 & & 1.50 & $\mathrm{~b}$ & 4.68 & $\mathrm{bc}$ & 1.28 & $\mathrm{a}$ & 6.00 & $\mathrm{a}$ \\
\hline Mombaça & 0.18 & $a b c$ & 0.23 & $\mathrm{a}$ & 0.09 & & 0.26 & & 3.22 & $\mathrm{a}$ & 7.25 & $\mathrm{a}$ & 0.65 & $\mathrm{~b}$ & 3.23 & $\mathrm{bc}$ \\
\hline Tanzânia & 0.12 & $\mathrm{c}$ & 0.24 & $\mathrm{a}$ & 0.10 & & 0.36 & & 1.79 & $\mathrm{~b}$ & 6.41 & $a b$ & 0.69 & $\mathrm{~b}$ & 3.82 & $\mathrm{~b}$ \\
\hline Aruana & 0.19 & $a b$ & 0.28 & $\mathrm{a}$ & 0.15 & & 0.37 & & 1.67 & $\mathrm{~b}$ & 4.60 & $\mathrm{bc}$ & 0.82 & $a b$ & 3.77 & $\mathrm{~b}$ \\
\hline Massai & 0.19 & $a b$ & 0.32 & $\mathrm{a}$ & 0.14 & & 0.47 & & 2.28 & $\mathrm{~b}$ & 5.27 & $a b c$ & 0.55 & $\mathrm{~b}$ & 2.63 & $\mathrm{bc}$ \\
\hline Mean & 0.18 & & 0.26 & & 0.13 & & 0.36 & & 2.21 & & 4.76 & & 0.77 & & 3.10 & \\
\hline$F$ test & & & & & & & & & & & & & & & & \\
\hline $\mathrm{N}$ & & & $* *$ & & & & $* *$ & & & & $* *$ & & & & $* *$ & \\
\hline Cultivar & & & $* *$ & & & & ns & & & & $* *$ & & & & $* *$ & \\
\hline $\mathrm{N} x$ Cultivar & & & $*$ & & & & ns & & & & $* *$ & & & & $* *$ & \\
\hline $\mathrm{VC}(\%)$ & & & 17.0 & & & & 32.1 & & & & 23.8 & & & & 27.1 & \\
\hline $2^{\text {nd }}$ harvest & & & & $\mathrm{g} /$ & & & & & & & & & & & & \\
\hline Marandu & 0.16 & $\mathrm{~b}$ & 0.27 & $\mathrm{~b}$ & 0.44 & a & 1.32 & a & 1.36 & $\mathrm{bc}$ & 4.93 & cd & 2.56 & $a b$ & 12.18 & $\mathrm{a}$ \\
\hline Xaraés & 0.21 & $\mathrm{~b}$ & 0.32 & $\mathrm{~b}$ & 0.50 & a & 0.36 & $\mathrm{c}$ & 2.00 & $a b$ & 8.28 & $\mathrm{bc}$ & 2.65 & $\mathrm{a}$ & 5.17 & $\mathrm{bc}$ \\
\hline Piatã & 0.36 & $\mathrm{a}$ & 0.23 & $\mathrm{~b}$ & 0.23 & $\mathrm{~b}$ & 0.83 & $\mathrm{~b}$ & 1.91 & $a b$ & 1.48 & $\mathrm{~d}$ & 1.01 & $\mathrm{~cd}$ & 3.78 & $\mathrm{c}$ \\
\hline Basilisk & 0.39 & $\mathrm{a}$ & 0.21 & $\mathrm{~b}$ & 0.14 & $\mathrm{~b}$ & 0.37 & $\mathrm{c}$ & 2.16 & $\mathrm{a}$ & 3.84 & $\mathrm{~d}$ & 0.72 & $\mathrm{~d}$ & 6.35 & $\mathrm{~b}$ \\
\hline Mombaça & 0.18 & $\mathrm{~b}$ & 0.50 & $\mathrm{a}$ & 0.41 & $\mathrm{a}$ & 0.27 & $\mathrm{c}$ & 1.92 & $a b$ & 17.89 & $\mathrm{a}$ & 1.72 & $\mathrm{bc}$ & 3.93 & $\mathrm{bc}$ \\
\hline Tanzânia & 0.14 & $\mathrm{~b}$ & 0.30 & $\mathrm{~b}$ & 0.25 & $\mathrm{~b}$ & 0.89 & $\mathrm{~b}$ & 1.41 & $a b c$ & 9.40 & $\mathrm{~b}$ & 1.13 & $\mathrm{~cd}$ & 12.21 & $\mathrm{a}$ \\
\hline Aruana & 0.14 & $\mathrm{~b}$ & 0.22 & $\mathrm{~b}$ & 0.20 & $\mathrm{~b}$ & 0.31 & $\mathrm{c}$ & 1.09 & $\mathrm{c}$ & 5.61 & bcd & 0.94 & $\mathrm{~cd}$ & 5.80 & $\mathrm{bc}$ \\
\hline Massai & 0.19 & $\mathrm{~b}$ & 0.31 & $\mathrm{~b}$ & 0.44 & $\mathrm{a}$ & 0.34 & $\mathrm{c}$ & 1.76 & $a b c$ & 9.72 & $\mathrm{~b}$ & 0.83 & $\mathrm{~d}$ & 3.35 & $\mathrm{c}$ \\
\hline Mean & 0.22 & & 0.30 & & 0.33 & & 0.59 & & 1.70 & & 7.64 & & 1.44 & & 6.60 & \\
\hline$F$ test & & & & & & & & & & & & & & & & \\
\hline $\mathrm{N}$ & & & $* *$ & & & & $* *$ & & & & $* *$ & & & & $* *$ & \\
\hline Cultivar & & & ** & & & & $* *$ & & & & $* *$ & & & & $* *$ & \\
\hline $\mathrm{N} x$ Cultivar & & & $* *$ & & & & $* *$ & & & & $* *$ & & & & $* *$ & \\
\hline $\mathrm{VC}(\%)$ & & & 23.9 & & & & 15.6 & & & & 29.7 & & & & 22.1 & \\
\hline $3^{\text {rd }}$ harvest & & & & & & & & & & & & & & & & \\
\hline Marandu & 0.38 & a & 0.30 & $\mathrm{c}$ & 0.08 & $\mathrm{~b}$ & 0.32 & $\mathrm{ab}$ & 1.72 & $\mathrm{bc}$ & 4.31 & d & 0.15 & $\mathrm{a}$ & 2.00 & $\mathrm{c}$ \\
\hline Xaraés & 0.38 & $\mathrm{a}$ & 1.09 & $\mathrm{~b}$ & 0.12 & $\mathrm{~b}$ & 0.32 & $\mathrm{a}$ & 1.80 & $a b c$ & 23.95 & $\mathrm{a}$ & 0.22 & $\mathrm{a}$ & 3.22 & $a b c$ \\
\hline Piatã & 0.27 & $a b$ & 1.82 & $\mathrm{a}$ & 0.20 & $\mathrm{a}$ & 0.31 & $a b c$ & 0.60 & $\mathrm{~d}$ & 5.06 & $\mathrm{~d}$ & 0.24 & $\mathrm{a}$ & 0.34 & $\mathrm{~d}$ \\
\hline Basilisk & 0.23 & $a b$ & 0.38 & $\mathrm{c}$ & 0.11 & $\mathrm{~b}$ & 0.25 & $a b c$ & 0.80 & $\mathrm{~cd}$ & 5.95 & $\mathrm{~d}$ & 0.27 & $\mathrm{a}$ & 3.30 & $a b c$ \\
\hline Mombaça & 0.15 & $\mathrm{~b}$ & 0.51 & $\mathrm{c}$ & 0.09 & $\mathrm{~b}$ & 0.21 & $\mathrm{bc}$ & 1.44 & bcd & 16.46 & $\mathrm{~b}$ & 0.32 & $\mathrm{a}$ & 2.86 & $\mathrm{bc}$ \\
\hline Tanzânia & 0.28 & $a b$ & 0.59 & $\mathrm{c}$ & 0.08 & $\mathrm{~b}$ & 0.26 & $a b c$ & 2.34 & $a b$ & 20.28 & $a b$ & 0.26 & $\mathrm{a}$ & 4.31 & $\mathrm{a}$ \\
\hline Aruana & 0.14 & $\mathrm{~b}$ & 0.29 & $\mathrm{c}$ & 0.10 & $\mathrm{~b}$ & 0.21 & $\mathrm{c}$ & 0.84 & $\mathrm{~cd}$ & 8.03 & $\mathrm{~cd}$ & 0.23 & $\mathrm{a}$ & 3.13 & $a b c$ \\
\hline Massai & 0.34 & $\mathrm{a}$ & 0.41 & $\mathrm{c}$ & 0.10 & $\mathrm{~b}$ & 0.23 & $a b c$ & 2.78 & $\mathrm{a}$ & 13.65 & $\mathrm{bc}$ & 0.13 & $\mathrm{a}$ & 4.03 & $a b$ \\
\hline Mean & 0.27 & & 0.67 & & 0.11 & & 0.26 & & 1.54 & & 12.21 & & 0.23 & & 2.90 & \\
\hline$F$ test & & & & & & & & & & & & & & & & \\
\hline $\mathrm{N}$ & & & $* *$ & & & & $* *$ & & & & $* *$ & & & & $* *$ & \\
\hline Cultivar & & & $* *$ & & & & $* *$ & & & & $* *$ & & & & $* *$ & \\
\hline N x Cultivar & & & $* *$ & & & & $* *$ & & & & $* *$ & & & & $* *$ & \\
\hline $\mathrm{VC}(\%)$ & & & 28.9 & & & & 20.6 & & & & 29.7 & & & & 25.6 & \\
\hline
\end{tabular}

Means followed by the same letter in each sub-column for each plant harvest are not significant at the $5 \%$ probability rate according to Tukey's test. **Significant at $1 \%$ probability; *Significant at $5 \%$ probability; ns, not significant.

and Mombaça cultivars had the lowest values. At high $\mathrm{N}$ rate, Aruana and Tanzania grasses had the lowest $\mathrm{N}$ concentrations in roots, while Basilisk cultivar had the highest $\mathrm{N}$ concentrations. At low $\mathrm{N}$ rate, $\mathrm{N}$ contents in roots were ranked in the following order: Mombaça = Aruana, Aruana > remaining cultivars, Mombaça $=$ Tanzania $=$ Massai, Mombaça $>$ Brachiaria cultivars and Tanzania = Massai = Brachiaria spp. At high N rate, Basilisk, Mombaça, Tanzania and Massai had high but equal amounts of $\mathrm{N}$ in roots, while Piatã cultivar had the lowest $\mathrm{N}$ content (this value was statistically similar to those of Marandu, Xaraés and Aruana cultivars). Nitrate concentrations in roots were lower in Piatã cultivar than in the Mombaça cultivar at low $\mathrm{N}$ rate (Table 4). At high rate, Brachiaria cultivars (Piatã $>$ Xaraés $=$ Marandu $=$ Basilisk) had higher nitrate concentrations in their roots than Panicum cultivars. However, at low $\mathrm{N}$ rate, the highest nitrate content in the roots was found in Mombaça cultivar, while Piatã cultivar had the lowest absolute value (this value was statistically similar to those of Brachiaria spp. and Massai). At high $\mathrm{N}$ rate, Marandu, Xaraés and Basilisk 
Table 4. Total nitrogen ( $\mathrm{N}$ total), nitrate $\left(\mathrm{NO}_{3}{ }^{-}\right)$and ammonium $\left(\mathrm{NH}_{4}{ }^{+}\right)$concentrations and contents in the roots of Brachiaria and Panicum cultivars grown at low and high nitrogen rates.

\begin{tabular}{|c|c|c|c|c|c|c|c|c|}
\hline \multicolumn{9}{|c|}{ Roots } \\
\hline \multirow[b]{2}{*}{ Cultivars } & \multicolumn{4}{|c|}{ Concentration } & \multicolumn{4}{|c|}{ Content } \\
\hline & \multicolumn{2}{|c|}{ Low N } & \multicolumn{2}{|c|}{ High N } & \multicolumn{2}{|c|}{ Low N } & \multicolumn{2}{|c|}{ High N } \\
\hline$N$ total & \multicolumn{4}{|c|}{$\mathrm{g} / \mathrm{kg}$} & \multicolumn{4}{|c|}{$\mathrm{mg} /$ pot } \\
\hline Marandu & 2.5 & bcd & 8.8 & $a b$ & 25 & c & 93 & $\mathrm{bc}$ \\
\hline Xaraés & 3.9 & $\mathrm{a}$ & 6.8 & $a b c$ & 31 & $\mathrm{c}$ & 89 & $\mathrm{bc}$ \\
\hline Piatã & 4.5 & $\mathrm{a}$ & 8.8 & $a b$ & 17 & c & 12 & $\mathrm{c}$ \\
\hline Basilisk & 3.4 & $a b c$ & 10.6 & $\mathrm{a}$ & 31 & $\mathrm{c}$ & 211 & $a b$ \\
\hline Mombaça & 2.3 & $\mathrm{~cd}$ & 4.9 & $\mathrm{bc}$ & 65 & $a b$ & 375 & $\mathrm{a}$ \\
\hline Tanzânia & 1.9 & $\mathrm{~d}$ & 4.6 & $\mathrm{c}$ & 47 & $\mathrm{bc}$ & 368 & $\mathrm{a}$ \\
\hline Aruana & 3.6 & $a b$ & 3.1 & $\mathrm{c}$ & 84 & $\mathrm{a}$ & 165 & $\mathrm{bc}$ \\
\hline Massai & 2.5 & bcd & 6.3 & bc & 42 & $\mathrm{bc}$ & 260 & $a b$ \\
\hline Mean & 3.1 & & 6.7 & & 43 & & 196 & \\
\hline \multicolumn{9}{|l|}{ F test } \\
\hline $\mathrm{N}$ & \multicolumn{4}{|c|}{$* *$} & \multicolumn{4}{|c|}{$* *$} \\
\hline Cultivar & \multicolumn{4}{|c|}{$* *$} & \multicolumn{4}{|c|}{$* *$} \\
\hline N x Cultivar & \multicolumn{4}{|c|}{$* *$} & \multicolumn{4}{|c|}{$* *$} \\
\hline $\mathrm{CV}(\%)$ & \multicolumn{4}{|c|}{21.6} & \multicolumn{4}{|c|}{23.0} \\
\hline $\mathrm{N}-\mathrm{NO}_{3}^{-}$ & \multicolumn{4}{|c|}{$\mathrm{g} / \mathrm{kg}$} & \multicolumn{4}{|c|}{$\mathrm{mg} /$ pot } \\
\hline Marandu & 0.06 & $\mathrm{ab}$ & 1.08 & $\mathrm{~b}$ & 0.54 & $\mathrm{~cd}$ & 12.71 & $\mathrm{a}$ \\
\hline Xaraés & 0.06 & $a b$ & 1.17 & $\mathrm{~b}$ & 0.45 & $\mathrm{~cd}$ & 15.11 & $\mathrm{a}$ \\
\hline Piatã & 0.05 & $\mathrm{~b}$ & 2.48 & $\mathrm{a}$ & 0.17 & $\mathrm{~d}$ & 3.58 & $\mathrm{~b}$ \\
\hline Basilisk & 0.05 & $\mathrm{ab}$ & 0.65 & $\mathrm{~b}$ & 0.46 & $\mathrm{~cd}$ & 12.40 & $\mathrm{a}$ \\
\hline Mombaça & 0.09 & $\mathrm{a}$ & 0.03 & $\mathrm{c}$ & 2.72 & $\mathrm{a}$ & 2.03 & $\mathrm{~b}$ \\
\hline Tanzânia & 0.06 & $\mathrm{ab}$ & 0.03 & $\mathrm{c}$ & 1.56 & $\mathrm{~b}$ & 2.01 & $\mathrm{~b}$ \\
\hline Aruana & 0.05 & $a b$ & 0.07 & $\mathrm{c}$ & 1.13 & $\mathrm{bc}$ & 3.80 & $\mathrm{~b}$ \\
\hline Massai & 0.05 & $a b$ & 0.06 & $\mathrm{c}$ & 0.96 & bcd & 2.65 & $\mathrm{~b}$ \\
\hline Mean & 0.06 & & 0.70 & & 1.00 & & 6.79 & \\
\hline F test & & & & & & & & \\
\hline $\mathrm{N}$ & & & $* *$ & & & & $* *$ & \\
\hline Cultivar & & & $* *$ & & & & $* *$ & \\
\hline N x Cultivar & & & $* *$ & & & & $* *$ & \\
\hline $\mathrm{CV}(\%)$ & & & 18.0 & & & & 32.0 & \\
\hline $\mathrm{N}-\mathrm{NH}_{4}^{+}$ & & $\mathrm{g} /$ & & & & & $/$ pot & \\
\hline Marandu & 0.10 & $\mathrm{~b}$ & 0.40 & $\mathrm{a}$ & 1.02 & cd & 5.07 & $\mathrm{a}$ \\
\hline Xaraés & 0.16 & $\mathrm{~b}$ & 0.41 & $\mathrm{a}$ & 1.28 & $\mathrm{~cd}$ & 5.36 & $\mathrm{a}$ \\
\hline Piatã & 0.16 & $\mathrm{~b}$ & 0.42 & $\mathrm{a}$ & 0.63 & $\mathrm{~d}$ & 0.62 & d \\
\hline Basilisk & 0.12 & $\mathrm{~b}$ & 0.23 & $\mathrm{~b}$ & 1.07 & $\mathrm{~cd}$ & 4.46 & $a b$ \\
\hline Mombaça & 0.12 & $\mathrm{~b}$ & 0.03 & $\mathrm{c}$ & 3.51 & $\mathrm{bc}$ & 2.16 & bcd \\
\hline Tanzânia & 0.30 & $\mathrm{a}$ & 0.07 & $\mathrm{c}$ & 7.75 & $\mathrm{a}$ & 5.55 & $\mathrm{a}$ \\
\hline Aruana & 0.17 & $\mathrm{~b}$ & 0.07 & $\mathrm{c}$ & 3.92 & $\mathrm{~b}$ & 3.62 & $a b c$ \\
\hline Massai & 0.18 & $\mathrm{~b}$ & 0.02 & $\mathrm{c}$ & 3.16 & bcd & 1.00 & $\mathrm{~cd}$ \\
\hline Mean & 0.16 & & 0.21 & & 2.79 & & 3.48 & \\
\hline F test & & & & & & & & \\
\hline $\mathrm{N}$ & & & $* *$ & & & & $*$ & \\
\hline Cultivar & & & $* *$ & & & & $* *$ & \\
\hline N x Cultivar & & & $* *$ & & & & $* *$ & \\
\hline $\mathrm{CV}(\%)$ & & & 34.0 & & & & 32.0 & \\
\hline
\end{tabular}

Means followed by the same letter in each sub-column are not significant at the $5 \%$ probability rate according to Tukey's test. **Significant at $1 \%$ probability.

cultivars had higher nitrate contents in the roots than other cultivars. At low $\mathrm{N}$ rate, ammonium concentration in the roots was higher in Tanzania cultivar than in the other grasses (Table 4). At high $\mathrm{N}$ rate, ammonium concentrations in Brachiaria cultivars $($ Marandu $=$ Xaraés $=$ Piatã $>$ Basilisk) were higher than in Panicum cultivars. At low $\mathrm{N}$ rate, ammonium contents in roots were higher in Tanzania and Aruana cultivars (Tanzania > Aruana) than in Brachiaria cultivars. At high $\mathrm{N}$ rate, ammonium contents were lowest in Piatã cultivar, whereas Marandu, Xaraés, Basilisk, Tanzania and Aruana cultivars had higher than the other cultivars, but statistically similar ammonium contents among them.

Proportions of total N, nitrate and ammonium in the plants

The contents of total $\mathrm{N}$, nitrate and ammonium in plants parts from the third harvest were used to calculate the relative proportions in grasses (only at third harvest were the roots collected together with the shoots of grasses). The most striking differences in $\mathrm{N}$ proportions occurred with Xaraés, 
Piatã, Basilisk and Aruana cultivars at low $\mathrm{N}$ rate, when these grasses had higher proportions of total $\mathrm{N}$ in their root systems than in the shoots (Fig. 1a, b). At high N rate, it was observed that: 1) Xaraés, Marandu and Piatã cultivars maintained the same nitrate proportions in roots as at low $\mathrm{N}$ rate; the proportions in the stems + sheaths were lower, and leaf proportions were higher than at low $\mathrm{N}$ rate; 2) Basilisk cultivar had significantly higher nitrate proportions in roots compared with low $\mathrm{N}$ rate; this cultivar also had lower and higher nitrate proportions in the stems + sheaths and leaves, respectively; 3) Panicum cultivars had higher proportions of nitrate in roots than at low $\mathrm{N}$ rate and lower proportions in the leaves and stems + sheaths (Fig. 1c, d). At both $\mathrm{N}$ rates, the highest proportion of ammonium was observed in roots. For Piatã cultivar, high $\mathrm{N}$ rate did not produce the same response as was observed in other cultivars, as much of the $\mathrm{N}$ applied to the soil was not absorbed by this cultivar (Fig. 1e, f). At high $\mathrm{N}$ rate, all cultivars retained a small proportion of ammonium in their shoots, especially in the leaves. However, Marandu, Xaraés and Basilisk grasses maintained same ammonium proportion in their leaves at both $\mathrm{N}$ rates; by contrast, Panicum cultivars had lower proportions of ammonium at high $\mathrm{N}$ rate than at low rate.

\section{$N$ use efficiency (NUE)}

The interaction $\mathrm{N}$ rates $\times$ cultivars was significant for NupE, NutE and NUE (Fig. 2). Cultivars had less efficient $\mathrm{N}$ uptake, utilization and use at the high $\mathrm{N}$ rate than at the low rate. NupE for Marandu cultivar was greater than for Aruana and Massai cultivars at low $\mathrm{N}$ rate (Fig. 2a). At high $\mathrm{N}$ availability, Aruana cultivar had greater NupE values than Marandu and Piatã cultivars. Mombaça and Tanzania cultivars had higher values of NutE than the other grasses at both $\mathrm{N}$ rates (Fig. 2b). At low $\mathrm{N}$ rate, Piatã cultivar had the lowest NutE value, while at high $\mathrm{N}$ rate, Piatã and Marandu cultivars had the lowest values. NUE was higher at low N rate (Fig. 2c). At low $\mathrm{N}$ availability, Mombaça cultivar had the highest NUE, followed by Tanzania and Xaraés cultivars. Under this same condition, Xaraés cultivar had the most $\mathrm{N}$ use efficiency among Brachiaria cultivars (although statistically not different from Marandu cultivar), even showing a higher efficiency than Aruana cultivar. At high N rate, Mombaça and Tanzania cultivars had equal $\mathrm{N}$ use efficiencies and were more efficient in their use of applied $\mathrm{N}$. At high $\mathrm{N}$ rate, Piatã cultivar had the least efficient use of $\mathrm{N}$, followed by Marandu, Basilisk and Xaraés cultivars.

\section{Discussion}

Studies have shown that increases in $\mathrm{N}$ applications in the soil result in increased $\mathrm{N}$ concentrations and contents in forage plants (Batista and Monteiro, 2008; Lavres Junior et al., 2010; Silveira and Monteiro, 2010; Muir et al., 2013). In this experiment, the $\mathrm{N}$ concentrations and contents differed among the grass cultivars. At both $\mathrm{N}$ rates and for all three harvests, Marandu and Piatã cultivars had the highest $\mathrm{N}$ concentrations in the leaves and stems + sheaths, and Mombaça and Tanzania cultivars had the lowest concentrations. The reverse trend was observed for the $\mathrm{N}$ content, as the cultivars with low concentrations exhibited high $\mathrm{N}$ contents (Table 1). The grasses that had the highest $\mathrm{N}$ concentrations were those that had higher nitrate concentrations in their shoots (Table 2). Mombaça cultivar always had lower nitrate concentrations in the leaves and stems + sheaths, while Piatã and Marandu grasses always had higher values. Nitrate contents in the shoots followed the same response patterns as did the $\mathrm{N}$ contents; cultivars with low nitrate concentrations had high nitrate contents in the shoots. It is known that grasses with higher nitrate concentrations in their shoots may have a high storage capacity for nitrate in their vacuoles. Absorbed nitrate can be reduced to ammonium, which is rapidly assimilated into organic compounds or can be accumulated in the vacuoles (Cárdenas-Navarro et al., 1999; Chen et al., 2004).

Ammonium concentrations in the leaves were similar among the grasses, especially at the high $\mathrm{N}$ rate; no clear patterns of responses were observed for the ammonium concentration in the stems + sheaths of grasses (Table 3). At the low $\mathrm{N}$ rate, the Marandu and Piatã cultivars had the highest ammonium concentrations in their leaves and stems + sheaths, while the Mombaça and Aruana cultivars had the lowest concentrations. The cultivars with the lowest ammonium concentrations in the shoots had high ammonium contents in this plant part. The small variations in the concentration and accumulation of ammonium in the shoots occur as ammonium is highly toxic to plant tissue cells and is therefore rapidly converted to amino acids (Marschner, 1995; Wang and Macko, 2011). The decrease in the $\mathrm{N}$ concentration and the increase in the $\mathrm{N}$ content in the shoots (as occurred with Mombaça cultivar) can be attributed to the dilution effect and the continuous increase in the amount of $\mathrm{N}$ taken up by this grass (Yuan et al., 2007), thus causing an increase in the proportion of structural and storage organs with low $\mathrm{N}$ contents and an increase in the production of plant dry matter (Greenwood et al., 1990; Primavesi et al., 2004; Corrêa et al., 2007). Cultivars that concentrated more $\mathrm{N}$ in their shoots (such as Marandu and Piatã grasses) did not appear to be capable of rapidly converting $\mathrm{N}$ into dry matter; therefore, these forages must have the ability to synthesize more N-rich compounds and/or possess a high storage capacity for the inorganic forms of this nutrient (Table 3).

In the root system, the high $\mathrm{N}$ rate produced an increase in the concentrations and contents of total $\mathrm{N}$, nitrate and ammonium in the grasses (Table 4). Brachiaria cultivars (mainly Piatã, Marandu and Xaraés) accumulated the most total $\mathrm{N}$, nitrate and ammonium in their roots when exposed to the high $\mathrm{N}$ rate. At this $\mathrm{N}$ rate, the Panicum spp., Mombaça, Tanzania and Massai cultivars had the highest total $\mathrm{N}$ content but the lowest nitrate content in the root system. This finding may be related to the rapid transport of absorbed nitrate to the shoots of these cultivars via the xylem (Marschner, 1995; Santos et al., 2002; Santos et al., 2012). Marandu, Xaraés and Piatã grasses apparently have the ability to accumulate greater amounts of $\mathrm{N}$ in their roots in the form of ammonium than do the other grasses; this feature may be related to their ability to easily assimilate ammonium (Table 4). Panicum cultivars experienced higher initial growth rates in the root system; this process favored the uptake of soil nutrients during the early stages of the lifecycle, the rapid assimilation of nitrate in the shoots and roots, the production of an increased number of nitrate transporters and a reduction in the activities of the nitrate-efflux channels (Burton 1943; Mackown et al., 2009; Acuña et al., 2010). All of the studied cultivars had higher $\mathrm{N}$ contents in their roots when exposed to a low $\mathrm{N}$ availability. These was most striking for Xaraés, Piatã, Basilisk and Aruana cultivars (Fig. 1a, b). Santos et al. (2002) and Santos et al. (2012) observed that $\mathrm{N}$ taken up in the roots was the primary source of $\mathrm{N}$ for the production of new leaves and lateral tillers in Panicum maximum cv. Tanzania and low $\mathrm{N}$ supply resulted in the mobilization of $\mathrm{N}$ to the root system.

The high $\mathrm{N}$ rate altered the proportion of nitrate contents in the cultivars in three different ways: 1) Xaraés, Marandu and 
Piatã grasses kept the same proportion of nitrate in their root system, reduced the nitrate content in the stems + sheaths and increased the leaf content; 2) Basilisk cultivar prioritized an increase in the nitrate proportion in the roots and leaves but lowered the proportion in the stems + sheaths; 3) Panicum cultivars greatly increased the proportion of nitrate in their root system but had small proportions in the leaves and stems + sheaths (Fig. 1c, d). These findings may indicate the following: 1) Xaraés, Marandu and Piatã grasses prioritized the accumulation of nitrate in the root system; it appears that in cases of excess nitrate, these grasses accumulate nitrate in the stems + sheaths and leaves, while a low $\mathrm{N}$ supply promotes an accumulation of nitrate in the leaves; 2) Basilisk cultivar prioritized the accumulation of nitrate in the root system and leaves when exposed to the low $\mathrm{N}$ rates; by contrast, large amounts of nitrate accumulated in the stems + sheaths in the presence of the high $\mathrm{N}$ rate; 3) Mombaça, Tanzania, Aruana and Massai cultivars prioritized nitrate accumulation in the root system at the low $\mathrm{N}$ rate; at the high $\mathrm{N}$ rate, Mombaça cultivar had the lowest proportion of nitrate in the root system, thus prioritizing its allocation to the leaves and stems + sheaths; and Aruana cultivar had the highest proportion of nitrate in the root system, as demonstrated by Santos et al. (2002) and Santos et al. (2012).

According to Scheurwater et al. (2002), nitrate to ammonium reduction in the roots may have more impact on the carbon requirements for nitrate assimilation compared to nitrate assimilation in shoots. Species that preferentially reduce nitrate in the shoots may have the advantage of being able to utilize the excess reducing power (NADH or NADPH and reduced ferredoxin) produced during photosynthesis (Raven et al., 1992; Kronzucker et al., 1997; Scheurwater et al., 2002); this appears to be the case for the Mombaça, Tanzania, Aruana and Massai cultivars. Conversely, species that reduce high amounts of nitrate in the roots (as appears to be the case with the Xaraés, Marandu and Piatã cultivars) lose the competitive advantage, as these species obtain their reducing power through the pentose phosphate and glycolysis pathways, which releases carbon dioxide and thereby increases the respiratory quotient of the plant. Therefore, the location of the nitrate reduction has an impact on the carbon balance of the plant (Oaks and Hirel, 1986; Bowsher et al., 1989; Marschner, 1995) and consequently on the dry matter production of grasses.

Most of the ammonium remained in the root system of all cultivars at high and low $\mathrm{N}$ rates, indicating that almost all of the ammonium assimilation occurs in the roots rather than in the shoots (Marschner, 1995; Wang and Macko, 2011). However, at the high $\mathrm{N}$ rate, the Marandu, Xaraés and Basilisk grasses maintained the same proportion of ammonium in their leaves as at the low $\mathrm{N}$ rate, while the Panicum cultivars had a reduced ratio (Fig. 1e, f). These cultivars may have a high capacity for ammonium assimilation in their shoots and therefore possess membrane transporters with more affinity for ammonium and/or a higher capacity for $\mathrm{N}$ storage in the form of ammonium in the shoots. Studies have shown that different species tend to prefer one inorganic form of $\mathrm{N}$ over another (von Wirén et al., 1997; Wallander et al., 1997; Garnett and Smethurst, 1999); other studies have shown that the preference for nitrate or ammonium can change throughout the day and may depend on whether the environment is wet or dry (Wang and Macko, 2011). Marandu, Xaraés and Basilisk cultivars may have this ability, as they experienced higher ammonium assimilation compared to the other grasses. This phenomenon may be related to the environment from which these cultivars were derived; the native soil of these plants may have had higher ammonium rates, resulting in a higher capacity to take up this form of $\mathrm{N}$.

Differences in the rates of accumulation and concentration of $\mathrm{N}$ may reflect changes in the NUE of the cultivars. Lemaire and Salette (1984) suggested that cultivars with a high dry matter production and a high NUE would have lower $\mathrm{N}$ concentrations in their tissues; this characteristic can result in forages that do not meet the nutritional requirements of ruminants (Brégarda et al. 2000), as forages with low N concentrations tend to have a low nutritional value (Andrade et al., 2000; Vitor et al., 2009; Santos et al., 2010). The cultivars that accumulated less $\mathrm{N}$ in their tissues (such as Mombaça and Tanzania grasses) had a high NUE at both N rates (Fig. 2c). The NupE was similar among the cultivars; the only observed difference was among the Marandu cultivar (which had a higher NupE) and the Aruana and Massai cultivars at the low $\mathrm{N}$ rate; at the high $\mathrm{N}$ rate, Aruana cultivar had a higher NupE than Marandu and Piatã cultivars (Fig. 2a). This finding may indicate that under conditions of low $\mathrm{N}$ availability in the soil, the Marandu cultivar may be more efficient in absorbing this nutrient. This higher NupE may be related to a better utilization of ammonium, which can provide a competitive advantage over time when the plant is cultivated in a restrictive environment. Conversely, in an environment with a high $\mathrm{N}$ availability, Aruana cultivar appeared to be best able to use the nitrate present in the soil solution. The variable that best explained the difference in the NUE in the grasses was the NutE (Fig. 2b). This finding indicates that cultivars prioritize the use of absorbed $\mathrm{N}$ differently; for example, Mombaça and Tanzania cultivars prioritize the allocation of $\mathrm{N}$ in the leaves at both $\mathrm{N}$ rates, while other cultivars do not (Fig. 1).

\section{Materials and Methods}

\section{Plant materials and greenhouse conditions}

This experiment was carried out during the summer season in a greenhouse located in Piracicaba, São Paulo State, Brazil, using the grasses Brachiaria brizantha cv. Marandu, $B$. brizantha cv. Xaraés, $B$. brizantha cv. Piatã, $B$. decumbens cv. Basilisk, Panicum maximum cv. Mombaça, $P$. maximum cv. Tanzania, $P$. maximum cv. Aruana and $P$. maximum $x P$. infestum cv. Massai. Seeds from these grasses were germinated in plastic trays containing washed sand with adequate moisture to provide a favorable germination environment. Seedlings were transplanted 12 days after sowing, when they had two to three leaves. Fifteen seedlings were transplanted in each pot and successively thinned to obtain five plants per pot.

Forage grasses were grown in plastic pots with a capacity of $4.2 \mathrm{dm}^{3}$ or $6 \mathrm{~kg}$ of soil for three growing periods; plant harvesting was performed at $5 \mathrm{~cm}$ above the soil surface. The first, second and third harvests occurred at 26, 24 and 22 days of growth, respectively, when the more mature leaves had begun to senesce. The mean temperature and humidity of the air inside the greenhouse during the experimental period was $29.6{ }^{\circ} \mathrm{C}\left(\operatorname{Tmax}=44.1{ }^{\circ} \mathrm{C} / \mathrm{Tmin}=19.5{ }^{\circ} \mathrm{C}\right)$ and $63.4 \%$, respectively.

The four Brachiaria spp. and four Panicum spp. cultivars were exposed to high $\left(300 \mathrm{mg} \mathrm{dm}^{-3}\right)$ and low $\left(30 \mathrm{mg} \mathrm{dm}^{-3}\right) \mathrm{N}$ rates using an 8 x 2 factorial design; similar experiments were conducted by Batista and Monteiro (2008) and De Bona and Monteiro (2010). The experiment was set as a complete randomized block design with four replications. Ammonium nitrate was used as $\mathrm{N}$ source. To avoid other potential limitations to growth, the nutrients $\mathrm{P}, \mathrm{K}, \mathrm{Ca}, \mathrm{Mg}, \mathrm{S}, \mathrm{B}, \mathrm{Cu}$, 
$\mathrm{Zn}$ and Mo were applied to the soil in amounts of 150,150 , $60,50,30,1.5,2.5,2.0$ and $0.25 \mathrm{mg} \mathrm{dm}^{-3}$, respectively, at the beginning of the experiment and after each harvest. Rates of $\mathrm{N}$ and $\mathrm{K}$ were split into three times, three days apart, to prevent an abrupt variation in the soil salinity. For the second and third growing seasons, the $\mathrm{P}$ concentration was reduced to $75 \mathrm{mg} \mathrm{dm}^{-3}$.

\section{Soil characterization}

The collected soil used in the experiment was an Entisol according to Embrapa (1999). The soil was air dried, sieved through a 4-mm mesh to remove gravel and coarse organic fractions (such as roots and leaves) and homogenized. The chemical characteristics of the soil prior to fertilization were as follows: $\mathrm{pH}\left(\mathrm{CaCl}_{2}\right)=4.2 ; \mathrm{OM}$ [organic matter] $($ dichromate/titration $)=13 \mathrm{~g} \mathrm{~kg}^{-1} ; \mathrm{P}($ resin $)=6 \mathrm{mg} \mathrm{kg}^{-1} ; \mathrm{K}$ (resin), $\mathrm{Ca}$ (resin), $\mathrm{Mg}$ (resin), $\mathrm{Al}(\mathrm{KCl}), \mathrm{H}+\mathrm{Al}$ (SMP buffer test), SB [sum of bases] and CEC [cation-exchange capacity] $=0.8,2.0,1.0,4.0,18.0,3.8$ and $21.8 \mathrm{mmol}_{\mathrm{c}} \mathrm{kg}^{-1}$, respectively, Ntotal $=170 \mathrm{mg} \mathrm{kg}^{-1}, \mathrm{~N}_{-\mathrm{NO}_{3}}^{-}=2.1 \mathrm{mg} \mathrm{kg}^{-1}$ and $\mathrm{N}-\mathrm{NH}_{4}{ }^{+}=2.4 \mathrm{mg} \mathrm{kg}^{-1}, \mathrm{~V}$ [percentage base saturation] $=17 \%$ and $\mathrm{m}$ [percentage aluminum saturation] $=51 \%$ (Raij et al,. 2001). Soil liming was performed using a value of $V_{2}$ equal to $50 \%$ in the formula for calculating the correction dose and using $\mathrm{CaO}$ and $\mathrm{MgO}$ (analytical reagents) to meet the mean nutritional requirements of the forage grasses. After liming material application, the soil was moistened with deionized water to reach a water-holding capacity of $70 \%$ and was incubated for a period of 25 days to allow the reaction of the applied liming material to take place.

\section{Irrigation system}

Water was supplied by using a self-irrigating subsurface system (Bonfim-Silva et al., 2007). Water was continuously replenished to maintain the soil at $70 \%$ water-holding capacity. The system for water replenishment was madd of a porous ceramic capsule $(5 \mathrm{~cm}$ in diameter and $7 \mathrm{~cm}$ in height) inserted into the soil surface in the pot upper portion. This capsule was connected to a $1.5-\mathrm{cm}$ diameter flexible tube and an 1.8-L capacity reservoir positioned below the pot. Soil water potential was determined by water column height (30 $\mathrm{cm})$ between the pot and the reservoir. Thus, soil-plant system evapotranspiration triggered the water automatic replenishment.

\section{Plant harvests, laboratory determinations and variable calculations}

At the end of each growth period, the grass shoots were harvested and separated into leaves and stems + sheaths, with the roots being separated only after the third harvest. The shoots and roots were ground in a Wiley mill and packed into plastic bags; the harvested portions were kept separate. $\mathrm{N}$ total concentration was determined as proposed by Sarruge and Haag (1974). Ammonium and nitrate concentrations were determined according to Tedesco et al. (1985).

The NUE, $\mathrm{N}$ uptake efficiency (NupE) and $\mathrm{N}$ utilization efficiency (NutE) were calculated. The NUE was determined by measuring the total yield of grass leaves (sum of yields for the three harvests) per unit of $\mathrm{N}$ applied. According to Moll et al. (1982), NUE depends on two parameters: NupE and NutE. NupE consists of the total $\mathrm{N}$ in the shoots of the collected plant divided by the total amount of applied $\mathrm{N}$, whereas NutE is defined as the dry leaf matter divided by the total amount of $\mathrm{N}$ in the shoots after harvesting (OrtizMonasterio et al., 1997; Hawkesford and Howarth, 2011).

\section{Statistical analysis}

Statistical analysis was done by using the "Statistical Analysis System" (SAS 2004) computer software. Experimental variables were subjected to an analysis of variance (ANOVA), and depending on the significance of the F-test, the Tukey's test for the comparison of means was used at a significance level of $5 \%$.

\section{Conclusion}

The studied forage grasses altered the partitioning of the total $\mathrm{N}$, nitrate and ammonium in the shoots and roots at $\mathrm{N}$ rates. All cultivars had the highest proportion of $\mathrm{N}$ in their roots when grown in conditions of low $\mathrm{N}$ availability. Cultivars with higher NUE, as Mombaça and Tanzania, had low concentrations of nitrogen, nitrate and ammonium in shoots and prioritize nitrate in roots only at low $\mathrm{N}$. The lowest NUE, as Marandu and Piatã had high concentrations of total N, nitrate and ammonium in shoots, prioritize nitrate in roots at both $\mathrm{N}$ rates and had high ammonium proportion in shoots, indicating increased tolerance of these cultivars to ammonium effects in tissues or greater ammonium assimilation in shoots. As the stress increase these cultivars may stay longer in the production system.

\section{Acknowledgments}

The authors thank the State of São Paulo Research Foundation (FAPESP), the Brazilian National Council for Scientific and Technological Development (CNPq) and the Coordination of Improvement of Higher Education Personnel (CAPES) for the financial support and scholarships.

\section{References}

Acuña CA, Sinclair TR, Mackowiak CL, Blount AR, Quesenberry KH, Hanna WW (2010) Potential root depth development and $\mathrm{N}$ uptake by tetraploid bahiagrass hybrids. Plant Soil. 334:491-499.

Andrade AC, Fonseca DM, Gomide JA, Alvarez VH, Martins CE, Souza DPH (2000) Elephant grass napier cv. mass production and nutritive value under increasing levels of $\mathrm{N}$ and potassium fertilizers. Braz J Anim Sci. 29:1589-1595.

Batista K, Monteiro FA (2008) Nitrogen and sulphur on morphogenic characteristics of marandu palisadegrass replacing signalgrass under degradation in a low organic matter soil. Braz J Anim Sci. 37:1151-1160.

Bonfim-Silva EM, Monteiro FA, Silva TJA (2007) Nitrogen and sulfur on yield and water-use efficiency of degrading signalgrass. Rev Bras Ciênc Solo. 31:309-317.

Bowsher CG, Hucklesby DP, Emes MJ (1989) Nitrite reduction and carbohydrate metabolism in plastids purified from roots of Pisum sativum L. Planta. 177:359-366.

Brégarda A, Bélanger G, Michauda R (2000) N use efficiency and morphological characteristics of timothy populations selected for low and high forage N concentrations. Crop Sci. 40:422-429.

Boddey RM, Macedo R, Tarré RM, Ferreira E, de Oliveira OC, Rezende CP, Cantarutti RB, Pereira JM, Alves BJR, Urquiaga S (2004) Nutrient cycling of Brachiaria pastures: the key to understanding the process of pasture decline. Agr Ecosyst Environ. 103:389-403.

Burton GW (1943) A comparison of the first year's root production of seven southern grasses established from seed. J Ame Soc Agro. 35:192-196. 
Cárdenas-Navarro R, Adamowicz S, Robin P (1999) Nitrate accumulation in plants: a role for water. J Exp Bot. 50:613624.

Chen BM, Wang ZH, Li SX, Wang GX, Song HX, Na X (2004) Effects of nitrate supply on plant growth, nitrate accumulation, metabolic nitrate concentration and nitrate reductase activity in three leafy vegetables. Plant Sci. 167:635-643.

Corrêa LA, Cantarella H, Primavesi AC, Primavesi O, Freitas AR, Silva AG (2007) Effects of sources and $N$ rates on forage production and quality of coastcross grass. Braz J Anim Sci. 36:763-772.

De Bona FD, Monteiro FA (2010) Marandu palisadegrass growth under nitrogen and sulphur for replacing Signal grass in degraded tropical pasture. Sci Agr. 67:570-578.

Embrapa (1999) Brazilian system of soil classification. In: Santos HG (ed.) Embrapa Solos, Rio de Janeiro, 1999.

Garnett T, Smethurst P (1999) Ammonium and nitrate uptake by Eucalyptus nitens: effects of $\mathrm{pH}$ and temperature. Plant Soil. 214:133-140.

Greenwood DJ, Lemaire G, Gosse G, Cruz P, Draycott A, Neeteson JJ (1990) Decline in percentage $\mathrm{N}$ of $\mathrm{C}_{3}$ and $\mathrm{C}_{4}$ crops with increasing plant mass. Ann Bot-London. 66:425- 436

Hawkesford MJ, Howarth JR (2011) Transcriptional profiling approaches for studying $\mathrm{N}$ use efficiency. Ann Plant Rev. 42:41-62.

Humphreys MW, Yadav RS, Cairns AJ, Turner LB, Humphreys J, Skot L (2006) A changing climate for grassland research. New Phytol. 169:9-26.

IBGE (2010) Sustainable development indicators. In: Forte LPS (ed.) Brazilian Institute of Geography and Statistics, Brasília, 2012.

Kronzucker HJ, Siddiqi MY, Glass ADM (1997) Conifer root discrimination against soil nitrate and the ecology of forest succession. Nature. 385:59-61.

Lemaire G, Salette J (1984) Relation entre dynamique de croissance et dynamique de pre-lèvement d'azote pour un peuplement de gramine-es fourragères. II. Étude de la variabilite- entre genotypes. Agronomie. 4:431-436.

Lavres Junior J, Santos Junior JDG, Monteiro FA (2010) Nitrate reductase activity and SPAD readings in leaf tissues of guinea grass submitted to nitrogen and potassium rates. Rev Bras Ciênc Solo. 34:801-809.

Mackown CT, Jones TA, Johnson DA, Monaco TA, Redinbaugh MG (2009) $\mathrm{N}$ uptake by perennial and invasive annual grass seedlings: N form effects. Soil Sci Soc Am J. 73:1864-1870.

Mahmood T, Kaiser WM (2003) Growth and solute composition of the salt-tolerant kallar grass [Leptochloa fusca (L.) Kunth] as affected by N source. Plant Soil. 252:359-366.

Marschner H (1995) Mineral nutrition of higher plants. In: Marschner H (ed.) Academic Press, London, 1995.

Moll RH, Kamprath EJ, Jackson WA (1982) Analysis and interpretation of factors which contribute to efficiency of $\mathrm{N}$ utilization. Agron J. 74:562-564.

Muir JP, Lee AE, Lambert BD, Reilley JL, Naumann HJ, Bow JR (2013) Dry matter, carbon, and N accumulation of four great plains grasses. Crop Sci. 53:1799-1808.

Oaks A, Hirel B (1986) N metabolism in roots. Annu Rev Plant Phys. 36:345-365.

Ortiz-Monasterio JI, Sayre KD, Rajaram S, McMahon M (1997) Genetic progress in wheat yield and $\mathrm{N}$ use efficiency under four N rates. Crop Sci. 37:898-904.

Parsons AJ, Edwards GR, Newton PCD, Chapman DF, Caradus JR, Rasmussen S, Rowarth JS (2011) Past lessons and future prospects: plant breeding for yield and persistence in cooltemperate pastures. Grass Forage Sci. 66:153-172.
Primavesi AC, Primavesi O, Corrêa LA, Cantarella H, Silva AG, Freitas AR, Vivaldi LJ (2004) N fertilization in coastcross grass: effects on nutrient extraction and apparent nitrogen recovery. Braz J Anim Sci. 33:68-78.

Rasmussen S, Parsons AJ, Jones CS (2012) Metabolomics of forage plants: a review. Ann Bot. 110:1281-1290.

Raven JA, Wollenweber B, Handley LL (1992) A comparison of ammonium and nitrate as $\mathrm{N}$ sources for photolithotrophs. New Phytol. 121:19-32.

Santos MER, Fonseca DM, Balbino EM, Silva SP, Monnerat JPIS (2010) Nutritive value of tillers and morphological components on deferred and nitrogen fertilized pastures of Brachiaria decumbens cv. Basilisk. Braz J Anim Sci. 39:1919-1927.

Santos PM, Thornton B, Corsi M (2002) N dynamics in the intact grasses Poa trivialis and Panicum maximum receiving contrasting supplies of N. J Exp Bot. 53:2167-2176.

Santos PM, Thornton B, Corsi M (2012) Adaptation of the C4 grass Panicum maximum to defoliation is related to plasticity of $\mathrm{N}$ uptake, mobilisation and allocation patterns. Sci Agr. 69:293-299.

Sarruge JR, Haag HP (1974) Análises químicas em plantas. In: Sarruge JR, Haag HP, ESALQ, Piracicaba, 1974.

SAS (2004) SAS® 9.1.2 windows. In: SAS Institute, Cary, 2004.

Scheurwater I, Koren M, Lambers H, Atkin OK (2002) The contribution of roots and shoots to whole plant nitrate reduction in fast- and slow-growing grass species. J Exp Bot. 53:1635-1642.

Silveira CP, Monteiro FA (2010) Macronutrients concentrations in Tanzania guineagrass diagnostic leaves supplied with nitrogen and calcium rates. Braz J Anim Sci. 39:736-745.

Tedesco MJ, Volkweiss SJ, Bohnen H (1985) Análises de solo, plantas e outros materiais. In: Tedesco MJ, Volkweiss SJ, Bohnen H (ed.) UFRS, Porto Alegre, 1985

Raij B van, Andrade JC, Cantarella H, Quaggio JA (2001) Análise química para avaliação da fertilidade dos solos tropicais. In: Raij vB (ed.) Instituto Agronômico de Campinas, Campinas, 2001.

Vendramini JMB, Sollenberger LE, Lamb GC, Silveira ML (2013) Herbage accumulation, nutritive value and persistence of Mulato II in Florida. Trop Grassland. 1:123-124.

Vitor VMT, Fonseca DM, Cóser AC, Martins CE, Nascimento Júnior D, Ribeiro Júnior JI (2009) Dry matter production and nutritional value of elephant grass pasture under irrigation and nitrogen fertilization. Braz J Anim Sci. 38:435-442.

von Wirén N, Gazzarrini S, Frommer WB (1997) Regulation of mineral N uptake in plants. Plant Soil. 196:191-199.

Wallander H, Arnebrant K, Ostrand F, Karen O (1997) Uptake of $15 \mathrm{~N}$-labelled alanine, ammonium and nitrate in Pinus sylvestris L. ectomycorrhiza growing in forest soil treated with N, sulphur or lime. Plant Soil. 195:329-338.

Wang L, Macko SA (2011) Constrained preferences in N uptake across plant species and environments. Plant Cell Environ. 34:525-534

Yaseen M, Malhi S (2009) Differential growth response of wheat genotypes to ammonium phosphate and rock phosphate phosphorus sources. J Plant Nutr. 32:410-432.

Yuan Z, Liu W, Niu S, Wan S (2007) Plant N dynamics and Nuse strategies under altered $\mathrm{N}$ seasonality and competition. Ann Bot. 100:821-830 